\title{
Senegambian megaliths as world cultural heritage
}

\section{Introduction}

Megaliths are human built features made of large stones. They are found in different part of the world with important concentrations in north tropical Africa (Figure 1). The megaliths from the Senegambia are now listed as UNESCO World Heritage. For a long time, they were exclusively a matter of experts' exegeses challenging each other in quasi-confidentiality. They are now brought to larger audiences worldwide. This interesting development, brought about by the prestigious "World Cultural Heritage", is clearly an insisting invitation for more research to understand the history of this phenomenon as well as its contribution to the formation of the unique Senegambian cultural landscape. ${ }^{1,2}$

If highly specialized debates can be conducted by experts at their own pace without urgency, the move to the status of world cultural heritage implies different approaches. It requires finding adequate answers to many of the important scientific, cultural, and heritage management issues that will necessarily emerged along the way. These answers are even more challenging when one always has to take into account present-day peoples inhabiting the more than $30,000 \mathrm{~km}^{2}$ Senegambian megalithic zone (Figure 2). This heritage is received from ancestors, still very poorly known. There is still no precise clue on their descendants. These are some of the major challenges cultural Heritage managers have to learn to deal with and researchers have to keep wrestling with.

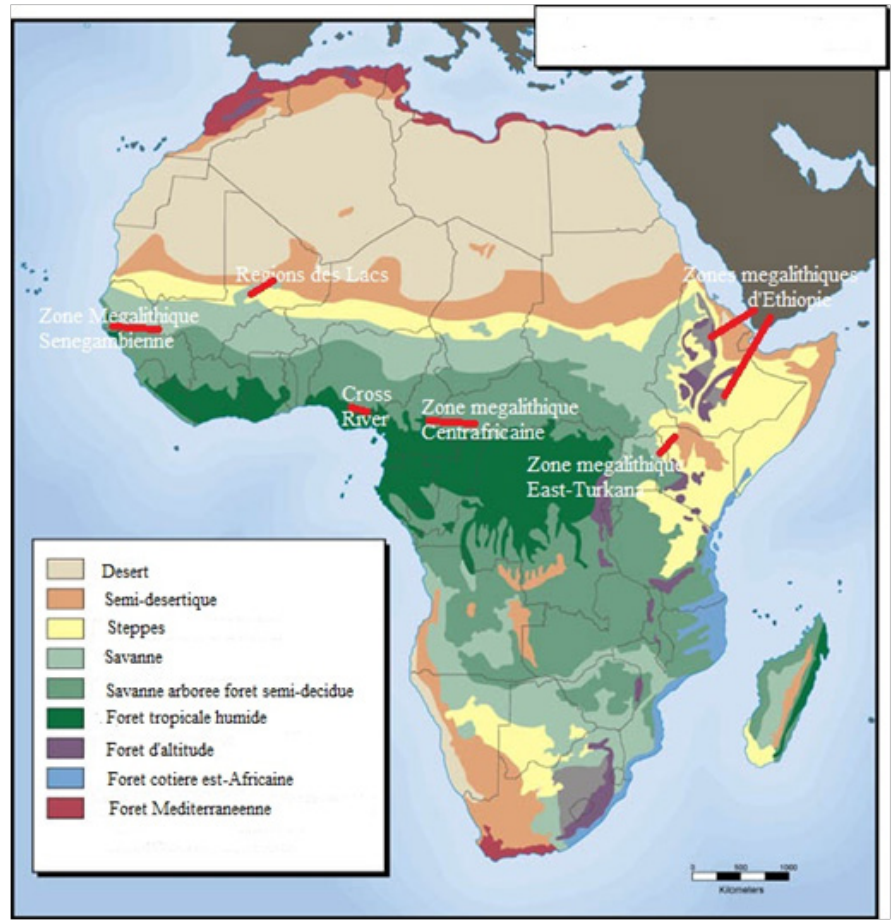

Figure I Location of major megaliths zones in Africa.

\section{The Megaliths from the senegambia}

The Senegambian megaliths zone is located in the westernmost
Volume 2 Issue 3 - 2018

\author{
Augustin FC Holl \\ Department of Anthropology, Xiamen University, Xiamen, Fujian, \\ PR China
}

Correspondence: Augustin FC Holl, Department of Anthropology, Xiamen University, Xiamen, Fujian, PR China, Email gaochang@xmu.edu.cn

Received: April 25, 2018 | Published: June 25, 2018

part of West Africa, in Senegal and the Gambia. The Gambia and Saloum rivers, 120 to $150 \mathrm{~km}$ apart. mark its southern and northern boundaries (Figure 2). It is stretched over $250 \mathrm{~km}$ west-east, approximately from the cities of Kaolack to Tambacounda. ${ }^{3-7}$ The area measures some $33,000 \mathrm{~km}^{2}$ with megalithic monuments concentrated along water courses (Figure 2). They attracted scholarly interest as early as the end of the 19th century, with sustained research efforts during the Colonial period. ${ }^{8-10}$ Captain Duchemin \& Jouenne $\mathrm{P}^{8,11}$ were two of these pioneers who devoted their activities to the search for the Senegambian megaliths builders. In 1903, Captain Duchemin ${ }^{8}$ excavated two monoliths circles at Dialato in Senegal. Taking notice of the unusual arrangement of human remains, he suggested the possibility for the practice of secondary burial. ${ }^{12,7}$ From 1915 to 1930 , Jouenne $\mathrm{P}^{11}$ a medical doctor, explored the central part of the megaliths zone, excavated 15 monuments in six different sites, and developed an elaborate and intriguing theory to account for the existence and structure of the monuments he has investigated. For Jouenne ${ }^{13}$ Senegambian megaliths are but another facet of an ancient solar religion, the "Sun Worship", geared to structure the spiritual life of ancient farming communities and fulfill the requirements of the agricultural cycle.

This short presentation reviews and summarizes the theories and explanations designed to make sense of the Senegambian megalithic phenomenon, and gain insight into the spiritual and symbolic life of the megaliths builders, who dotted the Senegambian landscape with their messages carved in stone. These monuments point to sophisticated rituals. They open access to refined and complex systems of beliefs that cannot be reified into predetermined categories.

\section{Framing good questions}

Who were the Megaliths builders? Where did they come from? Where did they go? What was their technical "know-how"? What were their motivations? These simple but challenging questions will not be addressed as precisely as one may wish in this paper, and this simply because the "megaliths still have a lot to say". Some answers will be long and intricate because they strive to convey the most accurate picture of the past, maintaining the difference between the secure achievements of scientific research and the product of simple speculations. With such an approach, visitors of megalithic sites will gain a better understanding of the sheer amount of research that is required from scientists. 


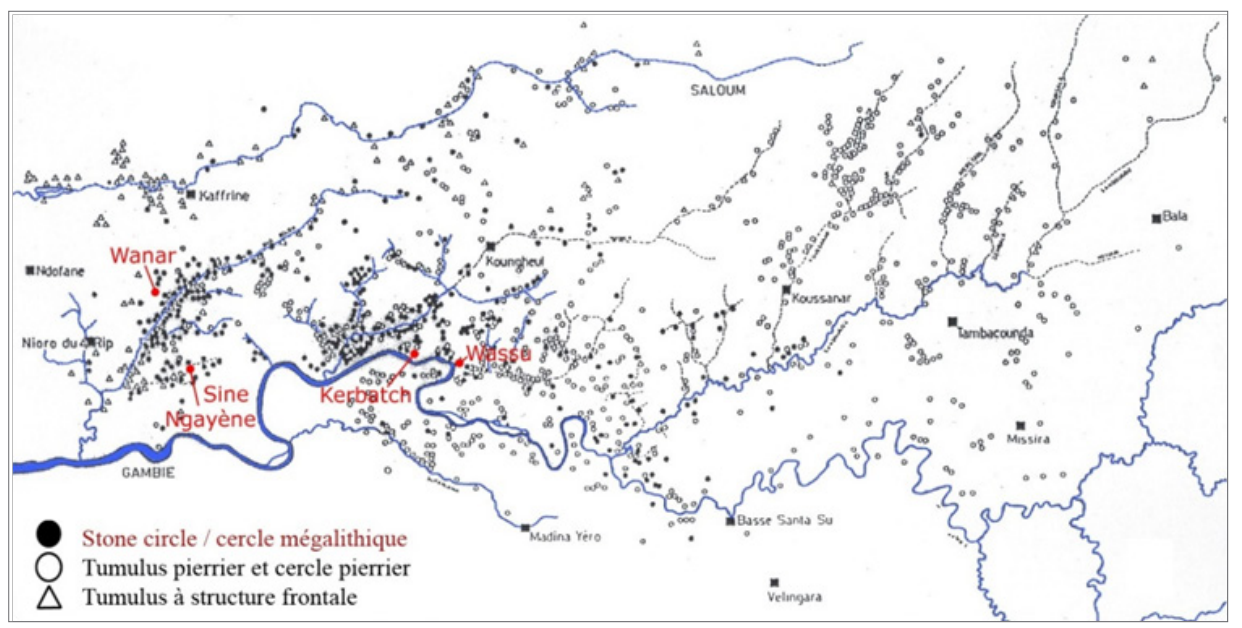

Figure 2 Map of the Senegambian Megaliths zone.

To investigate 1087 megalithic sites, approximately thirty thousand monoliths, cannot be done in the lifetime of an individual, not even within a generation. Step by step, many generations of researchers will strive to address these questions. For now, one has to do with what is available. Recent research has shown the archaeology of the Senegambian megaliths to be much more complex than previously thought. These new developments despite their limits are now part of a more elaborate and controlled scientific package. They provide cultural heritage managers with series of answers that give more coherence to the interpretation of this exceptional cultural landscape.

\section{The search for the megaliths builders}

Without over-simplification, "elusiveness" is the most accurate term to convey the perplexity of all those who have tried to grasp with the problems of origins and identity of the megaliths builders. The builders of Senegambian megaliths are intriguing. Their achievements are clouded in an opaque mystery. The relatively sudden emergence of the megaliths, the high quality of the workmanship involved in their construction, and the un-noticed exit from history of the megaliths builders are all part of the incredible saga of this archaeological enigma. This enigma has to be disentangled almost blindly, segment after segment, as there is nothing known of their cultural genealogy.

\section{Who were the megaliths builders?}

Despite the relatively large amount of human remains collected in the excavated megaliths monuments and sites from the beginning of the 20th century, bio-anthropological studies are still very limited. This is partly because of the very poor state of preservation and the practice of secondary burial that involves the selection of certain bones, skulls, long bones, jaws, etc. The selection criteria were certainly part of prescribed rules that guided the organization of funerals in the past. These rules are now completely opaque to contemporary researchers. As was the case for many other domains of the humanities and social sciences, research on the identity of megaliths builders did not escape from clichés. These monuments were considered too sophisticated to be built by native Black Africans and were attributed to people of European or Near-Eastern ancestry. They were successively claimed to have been Romans, Carthaginians, and Jewish. ${ }^{14-16}$ They could have been anything but African. These hypotheses lacking any archaeological backing were nonetheless representative of a certain state of mind prevalent in Africanist social sciences for many decades. All major cultural achievements to be documented in SubSaharan Africa were asserted to be of foreign-essentially NearEastern-origins. At that time of triumphant diffusionism, the aim of research was simply to look for the most probable ways and routes of transmission. The megaliths builders did not escape from that rule and archaeological data were needed for a change in perspective.

The first anthropometric survey and bio-anthropological studies indicate that people buried in the megalithic monuments are SubSaharan Africans, of the Sahelian type, thin and tall, measuring around $1.70 \mathrm{~m}$ in height for male adults, and practicing dental modifications still found among certain nationalities of the Senegambia. ${ }^{7}$ This level of identification does not allow connecting the megaliths builders with any precise present-day local group. However, new techniques like DNA analyses will hopefully open new perspectives on the research on the genealogy of megaliths builders.

\section{Where did they come from?}

In the present state of research there are no known local antecedents to the art of quarrying laterite blocks and shaping them into monoliths. Their sudden irruption in the Senegambian landscape is an enigma that needs to be deciphered through sustained research. The available chronology, the monuments themselves, and the current state of research do not yet allow for the construction of a coherent framework that may provide clues on the question of origins.

Up to 2000 , it was well known that megaliths were already being built in the second century BCE-(Before Common Era)-[no chronology is based on religious characters any more]. ${ }^{7}$ Recent research conducted at Sine Ngayene and Ngayene II point to an earlier emergence, around $1300 \mathrm{BCE} .{ }^{4,5}$ These exciting new and important chronological finds do not address the question of origins. There is a better understanding of the time of emergence of Senegambian megalithism but still no clue on the origins of the builders. It is not impossible for the local population to have initiated a stunning breakthrough that resulted in the development of megalithism. More research is however needed to look for the regional interaction sphere that may have included those who have initiated large stone quarrying on a grand scale. 
So far, the investigations on "origins" have been unsuccessful. On this point, one has to agree with the UNESCO Committee for World Heritage that Senegambian megaliths have an exceptional universal value. They are unique, without antecedents. It is simply known that those who built these monuments to honour their dead left a powerful spiritual message to the posterity.

\section{Where did they go?}

Logically, if one can assert that the obscure origins of the megaliths builders are intriguing, one is constrained to agree that their mysterious destiny is unsettling. Where did the megaliths builders go? The megalithic traditions from the Senegambia emerged without warning signs around $1300 \mathrm{BCE}$ and faded in the 15-16th century $\mathrm{CE}$ - Common Era-without traces connecting them to any of the existing contemporary nationalities. These enigmatic cultures are real research challenges considering the richness of the information to be recorded. Beside their unique, harmonious, and coherent architecture, Senegambian megaliths also include cultural and functional peculiarities non-existent in any other local community.

Lack of evidence and dearth of local sources provide room for wild speculations. It is therefore not surprising that a certain branch of scientific archaeology tiptoes around the big questions to focus exclusively on such basic issues as the description of monuments, their chronology, their material culture, and patterns of burial. Our ignorance is impressive. It is however difficult to accept that a population that had such an impact on the landscape, and had heavily invested its spirituality through the labour-intensive transformation of stones, simply vanished without traces.

There are nonetheless a number of anchor points in this sea of uncertainties. The first one is the shift marking the end of the megalithic traditions with the abandonment of burial in megalithic monuments. This radical shift took place between the $15^{\text {th }}$ and the $16^{\text {th }}$ century $\mathrm{AD}$, maybe later in some parts of the megalithic zone. A number of hypotheses can be suggested to explain the absence of any link between the megaliths builders and other nationalities from the Senegambia. In one, hard to accept, the megaliths builders simply vanished in a gigantic redistribution of population, victims to deadly epidemics or genocide, or a combination of both. In another hypothesis, new cultural standards and values may have spread all over the Senegambia confining the older megalithic traditions to cultural and social marginality. It is thus possible from then that a tight "law of silence - "omerta"-led to collective amnesia on the spectacular multi-millennial megalithic tradition.

In the current state of research and whatever hypothesis one decides to choose, it goes without saying that the origins as well as the end of the megalithic phenomenon are intriguing and unsettling. It appears as a floating cultural expression, drifting in space and time, without antecedents and descendants, but nonetheless imposing in its materiality. It is fascinating, disrupting, and a challenge to Cartesian logic. The result is an extraordinary research dynamics, with successive scholarly exegeses and revelations that shed some light and in the same movement reveals the extent of our ignorance, an invitation to further research.

\section{What was the extent of their technical knowledge?}

As shown in the previous section, it has been difficult to find anchor points in the quick-sand of the origins and demise of the megaliths builders. The situation is totally different when it comes to the study of material culture. It provides a well-documented entry to the technical knowledge and cultural environment of the megaliths builders. There is a good record that ranges from the production of monoliths to that of pottery, weapons, elements of personal adornment, as evidence for inter-regional and long distance trade. It allows for a better understanding of the life of the megaliths builders as well as part of their mortuary customs and rituals.

\section{The production and erection of monoliths}

The production and erection of monoliths is the most spectacular and specific aspect of the megalithic traditions. The ubiquitous laterite crust offers an unlimited source of raw material that was exploited by the megaliths builders. There is remarkable evidence of these activities at Sine Ngayene, Wanar, Wassu, and Ker Batch, among many others. Monoliths circles are arranged isolated or in groups (1 to 52) in different sites. They are made of carefully shaped cylindrical or polygonal standing stones that can reach $2 \mathrm{~m}$ above ground, and exceptionally more (Figure 3 ). An average size circle measures 4 to 6 $\mathrm{m}$ in diameter and is made of 8 to 18 erected monoliths. There are a handful of double concentric circles, 12 in total in the entire megaliths zone. All the monuments, circles and tumuli, generally have one or many standing stones on their east flank. Some of the monoliths have cup-marks or buttons on their top, the function of which has not yet been clarified. For Jouenne ${ }^{17,13}$ they are connected to the solar religion. The distribution maps ${ }^{6}$ show the monoliths with buttons to be confined to the west of the megaliths zone, those with cup-marks are widely spread in the rest of the area with some overlap in the centre. $\mathrm{Y}$-shaped standing stones are generally found in the frontal line of the monuments where they are generally associated with a large number of vessels, most with bored base. Megalithic sites with double frontal lines and Lyre-shaped stones are located in the central portion of the western megaliths zone. All these specific characteristics set the Senegambian megalithic zone apart, without any connection to any other megalith tradition in Africa (Mali, Cameroon, Central African Republic, Nigeria, Ethiopia) and the rest of the world. ${ }^{18}$ Despite the fact that they are made of stone, the megaliths are susceptible to natural and human-induced degradation. These factors have to be taken onto consideration for a sustainable management of this cultural heritage. Natural causes are derived from the quality of the raw material and include cracks that accelerate water infiltration and slow degradation of some monoliths, as well as the insufficient cementation of certain laterite crust that produced poor quality monoliths. The worst enemies of the monoliths are trees that disintegrate some monoliths circles and tumuli, cattle that trample the sites, lean on monoliths to scratch their skin and cause the collapse of some, fire used for clearing land that initiates thermal shocks, sharp temperature variations that can trigger cracks or split monoliths. There are few cases of human intervention that are detrimental to the preservation of megalithic site as is the case at Payoma. The village was literally set on one of the most remarkable megalithic site of the Senegambia, with monoliths up-rooted to be use as benches in public spaces.

\section{Production and use of iron}

Did the megaliths builders managed to produce iron on a large scale, a material they needed to quarry and shape the monoliths and manufacture weapons and many other objects they needed? In the current state of research it is difficult to a give a very precise and 
accurate answer to this question. It is nonetheless certain that they lived in a technological environment that included the production and use of iron.

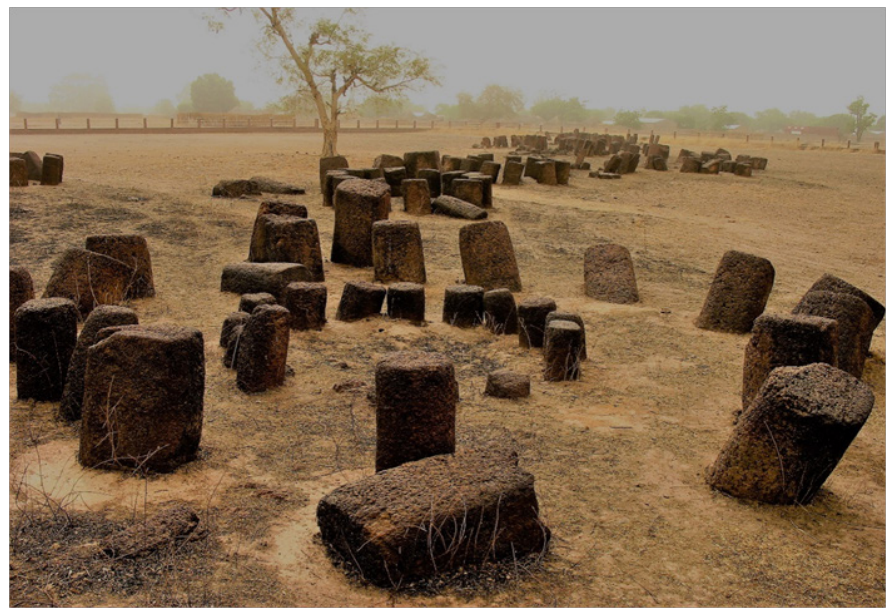

Figure 3 View of the southern part of Sine-Ngayene, from the central doublecircle, UNESCO World Heritage Site in Senegal.

At the level of the whole continent, there has been significant improvement in research on ancient metallurgy, and specifically iron technology. ${ }^{19}$ Many regions of the Sub-Saharan part of the continent have provided interesting evidence for the existence of iron metallurgy dating from the first millennium BC. In other regions like Agadez in Niger, iron metallurgy dates from the early part of the second millennium BCE, supporting the possibility for an autonomous emergence of this technology in Africa. The nearest neighbours of the Megaliths builders who had mastered iron technology at the very beginning of the first millennium BCE are to be found in the Middle Senegal Valley. ${ }^{20,21}$

No iron production workshop has been dated in the Senegambian megalithic area. Such workshops, as is the case for that of Ngayene II on the southeast flank of the megalithic cemetery, exist and are more numerous in the eastern part of the Megalithic zone. Further research will probably establish the chronology and the level of integration of these iron production workshops, cemeteries, and other habitation sites of Megaliths builders. Whatever the exact nature of these relationships, research has already shown the megaliths builders to have been astute and skilled users of iron.

Metallographic analyses conducted on a sample of iron implements collected from megalithic burials have shown a perfect fit between the objects-iron spearheads-and their symbolic use. The iron objects from Sine Ngayene submitted to advanced analyses ${ }^{22,23}$ were particularly elaborate spearheads with carefully crafted blade and bent tip. This observation, very common in the megalithic zone, points to a ritual practice in which the weapons were neutralized-de-commissioned-at the death of their owners and buried with them. The macrographic analysis of a spear (sample SEN. 75.56.XXVI) shows an overall homogeneity of the metal with low variability between different parts. These observations are supported by the micrographic analysis that revealed the artefact to be essentially made of ferrite with drops. The inclusions associated with the numerous cracks made the whole implement overtly fragile, made as it was with a low carbon metal with poor mechanical performances. All this information shows this spear to have been made for symbolic use congruent with the burial context from which it was collected, and not as an effective weapon. The information outlined above can be applied to another spear, (sample SEN.75.56.XXIV), made of two distinct pieces of metal with different carbon content that were welded to build the central axis of the artefact. Beside this central axis, the structural composition of the artifact is rather homogenous, a generalized ferrito-perlitic structure.

In summary, and in contrast to objects found in habitation sites, there is a lack of prolonged heat treatment, a poor quality of the weld and the importance of inclusions, all leading to mediocre weapons, if they were ever intended for such a use. However, when these artefacts are put in their right context of use, one is but struck by the overall coherence of the system. They were not designed to be used in combat in this world but to keep company to the deceased. This production geared toward a ritual use is further supported by their intentionally bent tips. The pragmatism and skill of the "megaliths builders" iron workers is plainly demonstrated in this case.

\section{Pottery production}

Pottery is clearly the most abundant component of the megaliths builders' material culture. It is represented by numerous complete vessels as well as thousands of sherds collected in the excavations of monoliths circles, tumuli, and others. If potsherds present an obvious cultural and statistical interest, complete or re-constructible vessels provide more reliable information. A large number of complete or virtually complete vessels have been found in the frontal zone of many of the excavated monuments. This frontal zone is the area delineated by the line of frontal monoliths in the east and the perimeter of the monument under excavation. Most of the vessels found in this context can be considered as mortuary production; most have a hole bored at their base, a feature reminiscent of the bent tip of the iron spearheads laid next to the deceased body.

The range of vessels shape to be found in the megalithic zone generally revolves around simple globular pots, with the most characteristic being carinated. There is nonetheless a wide range of shapes, with straight, thinned, convex, or concave rim. There is an increasing frequency of bevelled-rim sherds, characteristic of the coastal shell middens from the Sine, Saloum, Gambia River deltas and even the Casamance. The bevelled-rim is supposed to support a lid. The products from the coast could have been shipped through a complex of trade and exchange routes that linked the coast to the hinterland through the dense network of the Bolongs. In the Saloum delta, beside the bevelled-rim, this pottery is generally tempered with crushed shell. All these characteristics make of this ware a reliable indicator of contact between remote areas. The megaliths builders were in sustained contact with the coastal people who left the shell-middens along the littoral of the Senegambia. These contacts could have been based on the simple exchange of food stuff or much more elaborate, and in this case, involving the transfer of technical competence from one group to the other, as can be the case for matrimonial transfers in which women bring with them the skills learned in their parents' groups.

\section{A broad range of items of personal adornment}

The megaliths builders whose habitations sites are still very poorly investigated, left a rich testimony of elements of personal adornment. Besides the spearheads, discussed in the previous paragraph, archaeological research has allowed for the discovery of a broad range of artefacts, made of copper, alloyed copper, iron, glass and 
carnelian, and very likely many others that can be suspected like wood and leather.

The presence of copper at the early stages of megalithic burials points to an earlier than suspected use of this metal in Sub-Saharan Africa. The conventional wisdom dated the early use of copper to the later part of the first millennium BC. Recent research points to the very beginning of the first millennium B.C..$^{20}$ The date of SineNgayene tumulus 1, around $900 \mathrm{BC}$, supports this trend. The nearest copper sources could have been Akjoujt (Mauritania) for the earlier periods, and the Souss in Morocco for the later periods.

The elements of personal adornment in copper include skilfully crafted tronconical arm-rings, ear-rings, finger-rings, all found in burials. At Sine-Ngayene, both excavated tumuli that also include simple primary burials contained an impressive array of grave goods. It is as if the simplicity and the modesty of the architectural investment were compensated by an unusual wealth in grave goods. Carnelian, glass, and quartz are frequent among the beads collected from the excavated megalithic monuments. At Ngayene II, there are evidence suggesting a later use of megalithic monuments that may have lasted to the beginning of the Atlantic Trade system.

\section{The cultural landscape of the senegambian megalithic builders}

This paper has attempted to address most of the puzzling issues that are constitutive of the Senegambian megaliths problem. It goes without saying that these answers are partial at best and that much more research is needed. There are nonetheless a few core aspects that require respect, call for meditation, and humility. In fact, if the megaliths builders are silent, their impact on the landscape is simply stunning and exceptional. The listing of the Senegambian megaliths in UNESCO World Heritage in 2006 at Vilnius (Lituania) at the 30th Session of the Committee for World Heritage was the recognition of its exceptional universal value. It is a powerful legacy the megaliths builders left to the Senegambian people and the humanity as a whole.

This first trans-national listing is also a remarkable leap forward away from the sacro-saint boundaries inherited from the Colonial period. The legacy of the megaliths builders is a testimony of a strong cultural tradition unaffected by the imposed national borders. These monuments were the product of a creative and original African tradition and their listing in the UNESCO World Heritage is, in a certain sense, a celebration of the diverse forms of cultural expressions manifest through the four selected sites, two in each country, Sine Ngayene and Wanar in Senegal, Wassu and Ker Batch in the Gambia.

This choice is arbitrary. The country of megaliths builders measured some $30000 \mathrm{~km}^{2}$, with approximately thirty thousand monoliths, one monolith per square kilometre! The ultimate goal is the listing of the whole megalithic zone. In the meantime however, these four sites, all located in the western half of the megalithic zone, will be briefly presented below. They are among the most spectacular achievements of the megaliths builders and have been prepared to receive visitors.

\section{Sine ngayene}

Sine Ngayene: with 52 monoliths circle and more than 100 tumuli, this site is the most impressive of the whole megalithic zone. It is a well preserved site with the highest density of monoliths, 1102 in total, including monoliths with "button", a double-circle (called the King's tomb by local people), and a wealth of material culture collected through excavations (Figure 3 ). Jouenne $\mathrm{P}^{24}$ drew the first map of this site at the beginning of the 20th century and focused exclusively of the monoliths circles. The total number of monuments changed very little through time, from 49 to 52 . One of the monolith circle found isolated at some $150 \mathrm{~m}$ away in the northeast could not fit in the maps. It was excavated in 2003-2004 by Holl and Bocoum research team. ${ }^{1,3,5}$ A succession of excavation was conducted at Sine Ngayene, by Thilmans Descamps. ${ }^{25}$ This site appears to have been in use for at least two millennia. The previous chronology, based on a single radiocarbon date that assigned the whole site to the 10th century $\mathrm{AD},{ }^{7}$ has to be altered significantly. Holl Bocoum ${ }^{1,4,5,26}$ works point to a much longer use life. Sine Ngayene was in use for approximately two and half millennia, from the end of the second millennium B.C. to the first half of the second millennium A.D. It is now clear that there are some functional differences between the tumuli and monoliths circles. The former are single primary burials with extraordinarily rich assemblages of grave goods. The latter are collective secondary burials with relatively modest amount of grave goods. ${ }^{1}$

Beside the spectacular monoliths circles, Sine Ngayene is located near a very well preserved quarry, found at approximately one kilometer east, on the way to the village of Tiekene. This quarry was not use to manufacture large monoliths. Most of the pieces were elongated and cylindrical. The broken pieces abandoned on the site had micro-cracks or differential resistance that caused their breakage. The megaliths carvers had to master sophisticated knowledge of the material and high level of technical skill to quarry, ${ }^{27-31}$ carve, shape, and extract the monoliths from the laterite outcrop. The quarry is associated to tool-sharpening area (series of shallow basins and elongated grooves) where the equipment used for the quarrying operations was maintained on a constant basis. This area, an integral part of the megaliths production complex is worth visiting; it allows the visitors to appreciate at its right value the amount of work involved in the production of monoliths.

\section{Wanar}

Wanar is located at approximately 50 kilometers northwest of Sine Ngayene. It is comprised of only 21 monoliths circles but is still a spectacular site (Figure 4). The finishing touch on the bulky square section monoliths is particularly elaborate. It is also the case for the $\mathrm{Y}$ and inverted $\mathrm{A}$-shaped frontal stones (Figure 5). Wanar has the highest concentration of this kind of frontal stones. They have fascinated the visitors and some of them, fortunately not from this site, have been up-rooted and set somewhere else. The stones from Soto, a site located a few kilometres north of Wanar, are found today in the Gorée Historical Museum and the Musée du Quai Branly at Paris. There is an interesting quarry $200 \mathrm{~m}$ northeast of the site that is worth visiting in Senegal

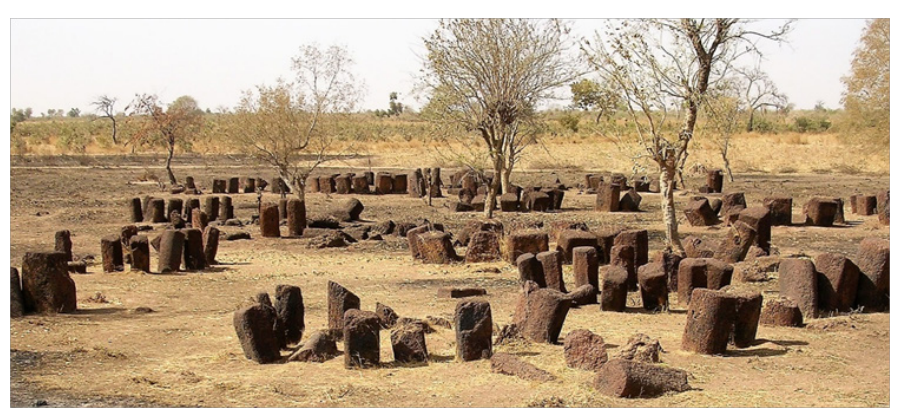

Figure 4 General view of Wanar, UNESCO World Heritage Site in Senegal. 


\section{Wassu}

Wassu with only 11 circles has the longest monolith of the Senegambia, measuring $2.59 \mathrm{~m}$ for the portion above ground (Figure 6,7). The site was studied in 1965 through the Anglo-Gambian Stone Circle expedition led by the archaeologist P. Ozanne. The excavation focused on two monoliths circles and provided some chronological insight pointing to the second half of the first millennium $\mathrm{AD}$ for the use of the monument.

\section{Ker Batch}

Despite its small number of features, 9 monoliths circles only, this

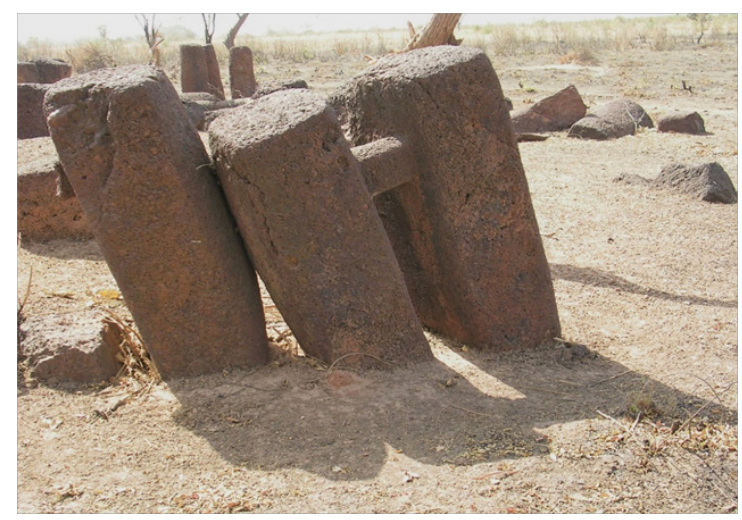

Figure 5 View of a specialY-shape frontal stone from Wanar, UNESCO World Heritage Site.

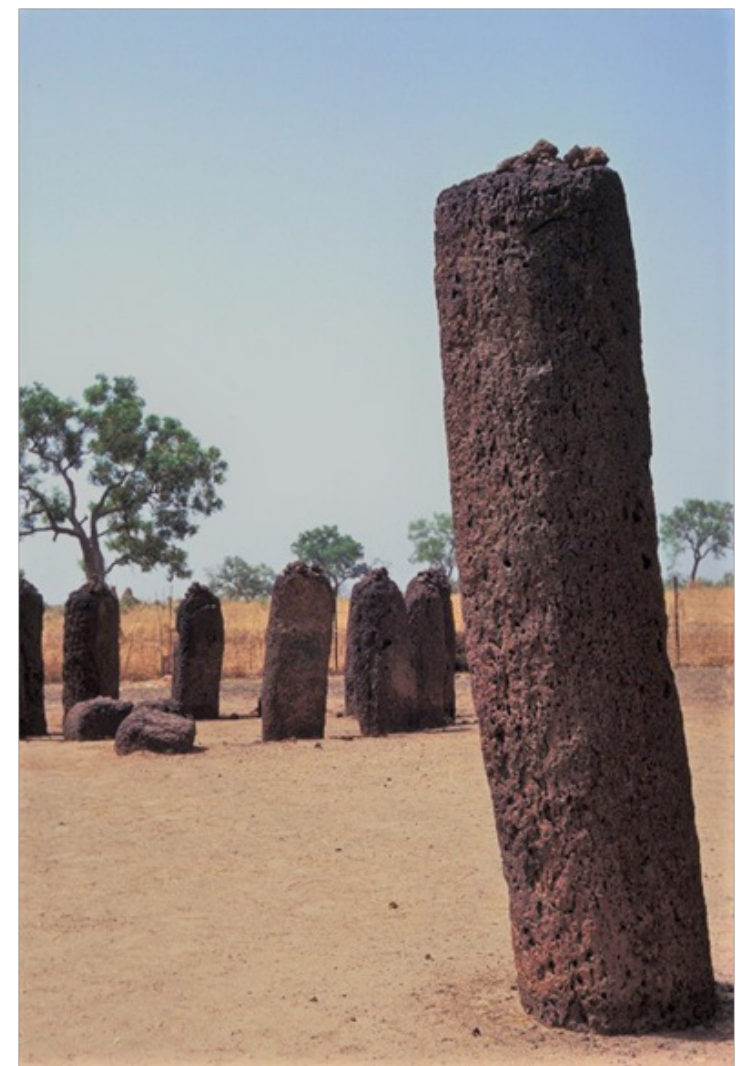

Figure 6 View of the longest monolith of the Senegambian megaliths zone at Wassu, UNESCO World Heritage Site in the Gambia. site is a microcosm of all the know-how of the megaliths builders (Figure 8). It has an impressive $\mathrm{Y}$-shaped frontal stone that was restored by the Anglo-Gambia expedition, and a double-circle like Sine Ngayene (Figure 9). The circle excavated by P. Ozanne had a rectangular pit at its center, with its sides lined with horizontally laid monoliths.

Wassu and Ker Batch are the most impressive sites from the Gambia. The former is comprised of 11 circles and the latter of 9, all very well preserved, easily accessible, with their well-designed on-site museums.

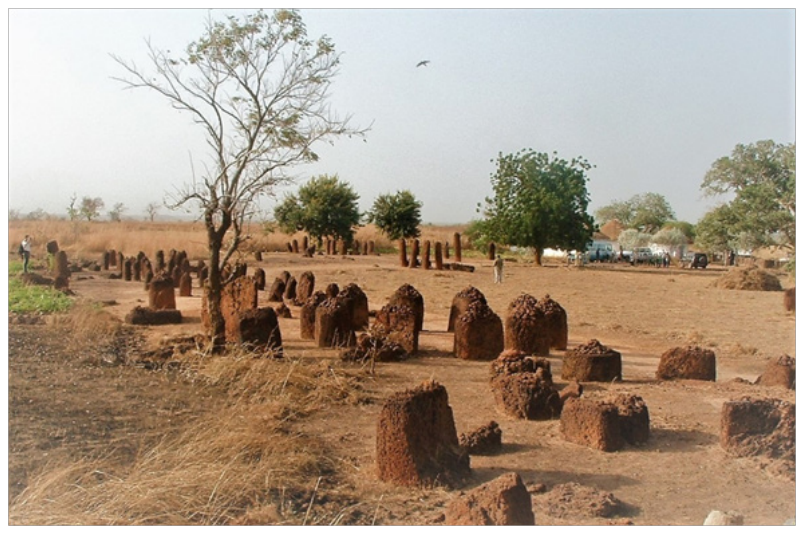

Figure 7 View of the monolith-circles from Wassu, UNESCO World Heritage Site in the Gambia.

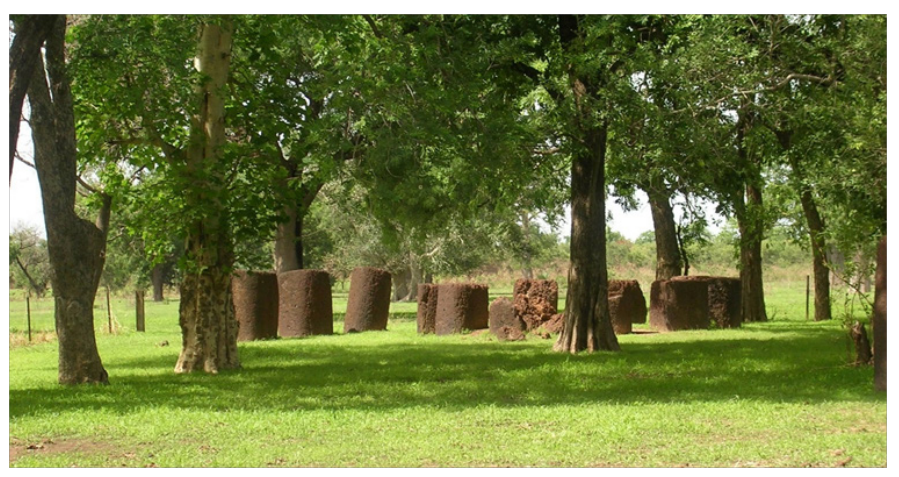

Figure $\mathbf{8}$ View of a monolith-circle from Ker Batch, UNESCOWorld Heritage Site in the Gambia.

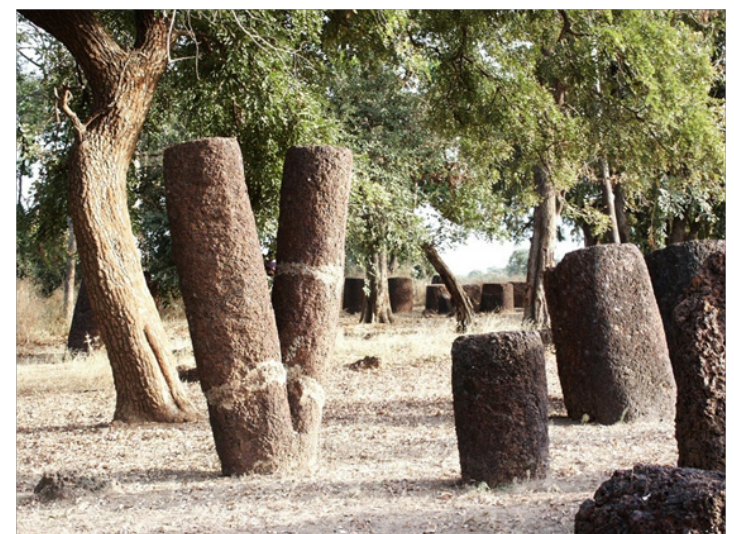

Figure 9 View of the Y-shape frontal stone of the double-circle from Ker Batch, UNESCO World Heritage site in the Gambia. 


\section{Conclusion:The exceptional universal value}

The construction of the monoliths circles from Senegambia attests to a know-how that has been recognized for its exceptional universal value. More than any other community around, the megaliths builders have been creative and innovators in their use of the laterite, a raw material they succeeded in shaping into simple blocks and elaborate monoliths, used in the construction of stone tumuli, monoliths circles, and $\mathrm{Y}$-shaped frontal stones; the latter are genuine architectural masterpieces. The knowledge involved in the construction of megaliths includes the identification of the most adequate laterite outcrops, with homogenous material and no or very few cracks. It would have been impossible to find the quarries that produced some 28,931 monoliths recorded in the Senegambian megalithic zone without this geological knowledge. The megalithic cemeteries, still enigmatic in many ways, are the last vestiges of these outstanding cultural traditions. Cultural traditions in which, creativity, daring, and adaptability have resulted in the formation of exceptional and stunning cultural landscapes. Even if the whole story of these sites is not yet known, the study of some burials has already revealed complex and elaborate mortuary practices. Future controlled excavations will certainly bring to light a diverse and rich array of information.

One cannot predict the future; however and whatever methodological or philosophical orientation one decides to rely on in future research, the megalithic sites will always be the testimony of a spiritual life, a conception of the world, life and death, that have required huge investments in time and labour without equivalent in West Africa. They point to a kind of African sense of religiosity carved in stone that reached us. The exceptional universal value of these monuments is acknowledged for all these reasons,. Their listing in the UNESCO World Heritage is the recognition of the unique and impressive character of the achievements of these builders. We have inherited this testimony. It is now our duty to preserve it and transmit it to the future generations.

\section{Acknowledgments}

None.

\section{Conflict of interest}

Author declares there is no conflict of interest.

\section{References}

1. Holl AFC, Bocoum H. Variabilité des Pratiques funéraires dans le Mégalithisme Sénégambien : Le Cas de Sine Ngayene. In: Descamps C, Camara A, editors. Sénégalia: Etudes sur le Patrimoine Ouest Africain. Paris, Editions Sépia; 2006:224-234.

2. Laporte L, Bocoum H, Bernard R, et al. Le Site megalithique de Wanar. Afrique: Archeologie et Arts. 2009;5:99-108.

3. Gallay A, Pignat G, Curdy P, et al. Mbolop Tobe (Santhiou Kohel, Senegal): Contribution à la Connaissance du Mégalithisme Sénégambien. Archives Suisses d'Anthropologie Generale.1982;46(2):217-259.

4. Holl AFC, Bocoum H. Les Traditions Mégalithiques de Sénégambie. Paris; Editions Errance; 2013.

5. Holl AFC, Bocoum H. Megaliths, Cultural Landscape, and the Production of Ancestors. Saarbrucken; Éditions Universitaires Européenne; 2017.

6. Martin V, Becker C. Inventaire des Sites Protohistoriques de la Sénégambie. Kaolack; 1984.

7. Thilmans GC, Descamps, Khayat B, et al. Protohistoire du Sénégal I: Les Sites Mégalithiques. Dakar; IFAN; 1980.
8. Duchemin, Capitaine. Quelques observations sur les tumulus de la vallée de la Gambie. Hamy ET, editor. Compte Rendus de l'Académie des Inscriptions et Belles Lettres. 1904:560-569.

9. Maxwell JW. Stone Circles in Gambia. Geographical Journal XII. 2000:522-527.

10. Todd JL. Notes on Stone circles in Gambia. Man.1903;93:164-166.

11. Jouenne P. Les Monuments mégalithiques du Sénégal. Annales et Memoires du Comité d'Etudes Historiques et Scientifiques de l'Afrique de l'Ouest. 1917:27-36.

12. Duchemin, Capitaine. Tumulus de Gambie. Bulletin et Mémoires de la Société d'Anthropologie de Paris T. $7 / 1$ et 2. 1906. p. 25-34.

13. Jouenne P. Les Monuments mégalithiques du Sénégal. Les Roches gravées et leur interpretation culturelle. Bulletin du Comité d'Etudes Historiques et Scientifiques de l'Afrique de l'Ouest. 1930. p. 309-399.

14. Migeod FWH. Stone Circles in the Gambia. Man. 1924;73:173.

15. Palmer HR. Stone Circles in the Gambia Valley. Journal of the Royal Anthropological Institute. 1939;69:273-283.

16. Parker H. Stone Circles in the Gambia. Journal of the Royal Anthropological Institute. 1923;53:173-228.

17. Jouenne P. Les Roches gravées du Sénégal. Bulletin du Comité d'Etudes Historiques et Scientifiques de l'Afrique de l'Ouest. 1920;1:1-42.

18. Joussaume R. Des Dolmens pour les Morts: Les Mégalithismes à travers le Monde. Paris; Hachette; 1985.

19. Bisson MS, Childs ST. Ancient African metallurgy: the Socio-cultural Context. Walnut Creek; AltaMira Press; 2000.

20. Bocoum H, McIntosh SK. Fouilles archéologiques à Sincu-Bara, Moyenne vallée du fleuve Sénégal. Nouakchott/Dakar: CRIAA; 2002. 197 p.

21. McIntosh RJ, McIntosh SK, Bocoum H, et al. The Search for Takrur: Archaeologcal excavations and Reconnaissance along the Middle Senegal Valley. New Haven/London; Yale University Press; 2016.

22. Bocoum H. Histoire technique et sociale de la Métallurgie du fer dans la Moyenne vallée du Fleuve Sénégal. Doctorat d'Etat es lettres et sciences humaines. Dakar; Université Cheikh Anta Diop; 2006.

23. Bocoum H, Fluzin P, Guillot I, et al. Apport de la métallographie structurale à l'interprétation fonctionnelle de trois objets en fer du Sénégal. Revue d'Archéométrie. 1988;12:57-69.

24. Jouenne P. Les Monuments mégalithiques du Sénégal. Bulletin du Comité d'Etudes Historiques et Scientifiques de l'Afrique de l'Ouest. 1918. p. 57-86.

25. Thilmans G, Descamps C. Le Site mégalithique de Tiekene-Boussoura (Sénégal). Fouilles de 1974-1975. Bulletin de l'IFAN, B. 1975;37(2):259306.

26. Holl AFC, Bocoum H, Dueppen S, et al. Switching Mortuary codes and Ritual Programs: The Double-Monolith-Circle from Sine-Ngayene, Sénégal. Journal of African Archaeology. 2007;5(1):127-148.

27. Duchemin, Capitaine. Les Mégalithes de la Gambie. L'Anthropologie 1905;16:633-638.

28. Metcalf P, Huntington R. Celebrations of death: The Anthropology of Mortuary Practices. Cambridge; Cambridge University Press; 1991.

29. Ozanne P. The Anglo-Gambian Stone Circles Expedition. Research Review. 1965;1:32-36.

30. Thilmans G, Descamps C. Le Site mégalithique de Tiekene-Boussoura (Sénégal). Fouilles de 1973-1974. Bulletin de l'IFAN, B. 1974;36(3):447496.

31. Thomas NW. Stone Circles in Gambia. Man. 1924;17:25-27. 